\title{
Quality characteristics of wheat-rice 'Makgeolli' prepared using rice 'Nuruk' and the potential probiotic Kazachstania exigua CCSY27
}

\author{
Chung Eun Hwang ${ }^{1,2}$, Kye Man Cho ${ }^{1}$, OK Soo Joo ${ }^{1 *}$ \\ ${ }^{1}$ Department of Food Science, Gyeongnam National University of Science and Technology, Jinju 52725, Korea \\ ${ }^{2}$ Department of Research \& Development, Jinju Bio Industry Foundation, Jinju 52839, Korea
}

\section{생균제제 효모 Kazachstania exigua CCSY27 및 쌀누룩을 이용하여 제조한 쌀-밀 막걸리의 품질 특성}

\author{
황정은 ${ }^{1,2} \cdot$ 조계만 ${ }^{1}$ - 주옥수 ${ }^{*}$ \\ 1경남과학기술대학교 식품과학부, ${ }^{2}$ (재)진주바이오산업진흥원 연구개발실
}

\begin{abstract}
In this study, a traditional Korean wheat-rice 'Makgeolli' was evaluated and the quality characteristics of the 'Makgeolli' prepared with rice 'Nuruk' and commercial 'Nuruk' sanseong, songhak, jinju, and the potential probiotic Kazachstania exigua CCSY27 yeast were determined. The $\mathrm{pH}$ of the 'Makgeolli' decreased during fermentation, while the acidity increased slightly. In particular, wheat-rice 'Makgeolli' made using commercial 'Nuruk' showed an acidity about 0.5 - 2.0-times higher than wheat-rice 'Makgeolli' made rice 'Nuruk'. The brix value increased sharply after fermentation for two days, with the value for wheat-rice 'Makgeolli' made using rice 'Nuruk' and sanseong 'Nuruk' observed to increase the most, to 9.2. The alcohol content of wheat-rice 'Makgeolli' made using rice 'Nuruk' was 7\%, which is higher than that of wheat-rice 'Makgeolli' made using commercial 'Nuruk' (sanseong, songhak, jinju), and was the best in terms of overall preference. The wheat-rice 'Makgeolli' made using rice 'Nuruk' and commercial 'Nuruk' was observed to brown slowly during fermentation, with the wheat-rice 'Makgeolli' made using sanseong 'Nuruk' having browned the most by the seventh day of fermentation. On the other hand, the wheat-rice 'Makgeolli' made from rice 'Nuruk', songhak 'Nuruk', and jinju 'Nuruk' exhibited total viable cell counts of lactic-acid bacteria and yeast of $10^{4}-10^{7}(\log \mathrm{CFU} / \mathrm{mL})$ during their the fermentation periods.
\end{abstract}

Key words : Kazachstania exigua CCSY27, alcohol fermentation, 'Makgeolli', rice 'Nuruk', wheat

\section{서 론}

막걸리는 멥쌀, 찹쌀, 보리 및 현미 등의 전분질을 주 원료로 하고 누룩을 발효제로써 첨가하여 제조한 병행 복발효주이다(Kim, 2017). 막걸리는 탁주 혹은 농주라고 도 불리며 쌀이 귀하던 시절에는 밀가루와 옥수수를 이용 하여 술을 빚었으나, 오늘날에는 생활수준 향상 등으로 인해 쌀 또는 쌀-밀 막걸리가 주종을 이룬다. 막걸리는
한국 고유 전통술로 단맛, 신맛 등의 맛과 청량감이 있는 알코올 함량 2-8\% 정도의 술로써 시중에 판매되고 있다 (Woo 등, 2010a; Kim 등, 2011a). 특히, 일반 주류와는 달리 단백질, 당질, 비타민, 식이섬유와 같은 영양성분이 풍부하 여 영양가가 우수한 것으로 알려져 있다(Kim, 2017). 막걸 리 담금 후에는 누룩 곰팡이, 유산균, 효모에 의한 효소 작용으로 인해 정장 작용과 기능성 물질이 생성되므로 독특한 풍미를 가지게 된다(Song과 Park, 2003; Kwak 등,

*Corresponding author. E-mail : osjoo@gntech.ac.kr, Phone : +82-55-751-3273, Fax : +82-55-751-3279

Received 28 January 2020; Revised 07 February 2020; Accepted 10 February 2020.

Copyright (c) The Korean Society of Food Preservation.

This is an Open Access article distributed under the terms of the Creative Commons Attribution Non-Commercial License (http://creativecommons.org/licenses/by-nc/4.0) which permits unrestricted non-commercial use, distribution, and reproduction in any medium, provided the original work is properly cited. 
2014). 또한, 신진대사를 촉진시키는 유산균이 막걸리 종 류에 따라 약간의 차이를 보이나 일반적으로 막걸리 700 $\mathrm{mL}$ 에 약 $7 \times 10^{10}$ 이상의 생균수를 함유하고 있는 것으로 보고되었다(Song 등, 2009). 이러한 막걸리의 기능성은 발 효의 주체가 되는 미생물과 그 대사산물에 의해 결정되므 로 맛과 기능성까지 고려한 소재개발이 가능하다(Rhee 등, 2014). 발효 과정 중 효모와 곰팡이는 전분을 포도당 단위 의 단당류로 분해하면서 최종 산물인 알코올을 생성하고, 이와 동시에 유산균은 젖산을 생성하여 보존의 효과를 높여준다(Shin 등, 2017). 그러나, 최근 막걸리 제조방법이 한국전통방식이 아니라는 문제점이 지속적으로 제기되었 다(Cho 등, 2012). 막걸리의 발효제는 전통방식으로 제조 되는 누룩이지만, 대부분 일본에서 사용하는 코지(입국) 방식으로 제조하고 있는 현실이다(So와 Lee, 2009). 누룩 의 유래는 삼국시대부터 양조에 사용되었으며 제조방법과 빛깔에 따라 황국균(Aspergillus oryzae), 흑국균(Aspergillus niger), 홍국균(Monascus sp.) 등이 있으며 막걸리에 쓰이는 것은 주로 황국균이다(Cho 등, 2012). 한편, 누룩의 종류, 제조장 및 제조과정에 따라 상이한 미생물들이 관여 하며 각종 효소활성도에 따라 유기산, 알코올 함량 등이 크게 달라지므로 이러한 각종 인자들은 막걸리의 품질을 결정 하는데 있어 아주 중요한 요소이다(Han 등, 1997; Woo 등, 2010b).

최근에는 경제 성장에 따른 생활수준 향상으로 식생 활에도 많은 변화를 가져온 상태이다. 특히, 건강에 대한 관심은 이미 오래전부터 높아진 상태로 농산물 원료에 대한 안전성과 고품질의 농산물을 소비자들은 선호하고 있다(Seo 등, 2012). 농산물 중 한국 고유 품종의 밀은 신라와 백제시대때부터 경작해온 아주 오래된 작물이다 (Seo 등, 2012). 그러나, 한국에서 소비되는 밀은 대부분 수입산을 사용하고 있는 실정이며 이에 따라 한국 밀의 소비량을 늘리기 위한 운동이 추진되어 재배면적이 증 가하였으나, 한국 밀 가공품으로는 제빵(국수, 파스타 면) 관련 식품으로 이미 한계에 부딪힌 실정이다(Kim 등, 2011b). 이에 따라 우리밀 자급률과 소비율을 증대시 키기 위해 새로운 가공품 개발이 필요할 것으로 사료된 다(Kim 등, 2011c). 한편, 막걸리와 관련된 연구로는 주 원료인 밀 또는 쌀 외에 다양한 원료를 첨가한 것이 대부 분으로 수수(Woo 등, 2010b), 현미(Lee 등, 2014), 보리 (Park 등, 2015), 율피가루(Jeong 등, 2006), 팽화미분(Kim 등, 2007) 등의 연구가 보고되었다. 이 밖에도 생리활성 (Kim 등, 2012; Jung과 Kim, 2015) 및 항균활성(Sim과 $\mathrm{Kim}, 2016)$ 에 대한 연구도 보고되기도 하였다. 하지만 각종 누룩에 대한 막걸리 비교 연구는 부족한 것으로 조사되었다.

따라서 본 연구에서는 한국의 전통누룩에서 분리한
Rhizopus oryzae CCS01(Seo 등, 2012) 균주로 제조한 쌀 누룩과 시판누룩(산성, 송학, 진주)으로 막걸리를 1단 담금 하고, 여기에 생균제제능이 우수한 Kazachstania exigua $\mathrm{CCSY} 27$ 효모 균주로 2단 담금하여 최종적으로 제조하여 누룩 종류와 발효 과정에 따른 막걸리의 품질 특성을 비교 분석하는데 그 목적이 있다.

\section{재료 및 방법}

\section{재료 및 시약}

본 연구에서 막걸리 제조에 사용한 멥쌀은 한국 경상남 도 함양군 소재 함양농협미곡처리장에서 구입하였고, 밀 은 진주시 소재 반성면에서 재배된 금강 품종의 우리밀을 사용하였으며, 대조구로 사용한 시판 누룩은 진주시 중앙 시장에서 통상적으로 판매되고 있는 산성 누룩, 송학 누룩, 진주 누룩을 구입하여 사용하였다.

\section{선발 효모 균주 분리 및 동정}

쌀누룩 제조에 사용한 Rhizopus oryzae 곰팡이 균주는 이전 연구결과에서 분리된 것을 사용하였다(Cho 등, 2012). 선발된 효모는 우선 chloramphenicol( $1.5 \mathrm{mg} / \mathrm{mL})$ 이 함유된 potato dextrose agar(PDA, Difico, Becton, Dicnso, Co., Sparks) 배지에 도말하여 $37^{\circ} \mathrm{C}$ 에서 3 일간 배양 후 $16,500 \mathrm{rpm}$ 의 속도로 3 분간 원심분리하여 배양액은 거른 뒤 균체만을 회수하였으며, 이 과정을 3회 반복하여 균체 를 수집하였다. 확보된 균체는 DNAzol kit(iNtRON Biotechnology, Suwon, Korea)를 사용하여 일련의 과정을 통해 genomic DNA를 분리하였다. 분리된 genomic DNA 를 주형으로 하여 26S rDNA PCR(Bio-Rad, Hercules, CA, $\mathrm{USA})$ 증폭을 수행하였다. $\mathrm{PCR}$ 증폭은 1 분간 변성 $\left(94^{\circ} \mathrm{C}\right)$, 30 초간 풀림 $\left(52^{\circ} \mathrm{C}\right)$ 및 신장 $\left(72^{\circ} \mathrm{C}\right)$ 과정을 30 회 반복 수행 하였다. 한편, $26 \mathrm{~S} \mathrm{rDNA}$ 단편 증폭을 위한 primer는 Joo 등(2011) 연구방법에서 사용한 균주를 사용하였다. PCR 증폭 후에는 증폭된 $26 \mathrm{~S} \mathrm{rDNA}$ 산물은 agarose $(1 \%)$ 에 전기 영동하고 단편 $(0.6 \mathrm{~kb})$ 을 회수하여 pGEM-T Easy 벡터를 사용하여 클로닝하였다. 클로닝 후, Escherichia coli $\mathrm{DH} 5 \alpha$ 에 형질전환 후 형질전환체를 PDA 배지에 무작위로 순수 분리하였다. 순수분리한 형질전환체를 항생제(ampicillin) 함유 Luria Bertani 배지(LB, Difico, Co., Detroit, MI, USA) 에 접종하여 16 시간 $\left(37^{\circ} \mathrm{C}\right)$ 배양 후 균체를 수집하고 plasmid 정제 kit(Intron, Suwon, Korea)에 수록된 절차대로 plasmid를 분리 및 정제하였다. $26 \mathrm{~S}$ rDNA 염기서열 분석 은 BLAST Search Service와 미국 국립생물정보센터 (NCBI)에서 얻은 기존에 알려진 다른 균주들과 비교분석 하여 최종적으로 동정하였다. 


\section{생균제제(내산성, 펩신 저항성, 담즙산 내성) 효모 확보}

생균제제 효모를 확보하기 위해 균주 분리는 우선 전통 주(탁주)와 식초, 식물효소발효액으로부터 최초 200여 종 이상의 전형적인 효모 형태의 콜로니를 분리하여 $\mathrm{PDA}$ 배지에 배양 및 확보하였다. 이후 백미와 도정밀에서 알코 올 발효능과 발효특성(맛, 향 등)이 우수한 효모 균주를 잠정적으로 22 종을 선정하였다.

내산성 검증은 분리된 효모들을 potato dextrose broth (PDB, Difico, Becton, Dicnso, Co., Sparks) $\left(30^{\circ} \mathrm{C}\right)$ 배지에서 2 일간 배양시키고, $3 \mathrm{M} \mathrm{HCl}$ 을 첨가하여 $\mathrm{pH} 3.0$ 으로 조정된 새로운 $\mathrm{PDB}$ 배지에 $10^{6} \mathrm{CFU} / \mathrm{mL}$ 의 농도로 새로이 접종하 였다. 접종된 효모들을 $37^{\circ} \mathrm{C}$ 에서 3,6 시간 배양 후 $\mathrm{PDA}$ 배지에 도말하여 생균수를 측정하였으며 생존율은 초기 세포 농도와 PDA 배지상에 형성된 효모의 colony 비율을 비교하여 \%로 계산하였다(Kang과 Lee, 2012).

펩신 저항성은 $\mathrm{PDB}$ 배지에 펩신 $(1 \%)$ 을 첨가하여 $\mathrm{pH}$ 를 3.0 으로 조절하여 인공위액산 환경을 제조하였으며, 측정 방법은 내산성과 동일한 방법으로 실시하였다(Kang과 Lee, 2012).

담즙산 내성은 $\mathrm{Ha}$ 등(2004)의 방법을 조금 변경하여 측정하였다. Mann Rogosa Sharp(MRS, Becton, Dicnso, Co., Sparks) 배지에서 2 일간 배양한 균체 $\left(30^{\circ} \mathrm{C}, 10^{6} \mathrm{CFU} / \mathrm{mL}\right)$ 를 다른 농도 $(1.0-4.0 \% \mathrm{w} / \mathrm{v})$ 의 담즙산 함유 MRSA 배지상에 spoting 하였다. 그 후 $37^{\circ} \mathrm{C}$ 에서 2 일간 배양하였으며, 담즙 산의 최소저해농도는 spot을 육안검사로 판정하고 spot 에서 균 생장을 전적으로 저해시키는 최소농도로 결정 하였다.

\section{R. oryzae CCS01 곰팡이 이용 누룩제조}

막걸리 담금 전, 누룩 제조를 위해 우선 $R$. oryzae CCS01 곰팡이 포자를 $\mathrm{PDA}$ 배지에 이식 및 성장시킨 뒤 곰팡이 배양 plate를 멸균증류수 $(100 \mathrm{~mL})$ 에 현탁시키고 살균된 탈지면에 여과하여 포자 $(6.0 \log \operatorname{spores} / \mathrm{mL})$ 를 수집하고, 누룩 제조를 위한 종균으로 사용하였다. 한편, 누룩 제조는 멥쌀 $6 \mathrm{~kg}$ 을 깨끗한 물로 충분히 세척 후 상온 $\left(25^{\circ} \mathrm{C}\right)$ 에서 하루가량 침지시킨 후 1 시간 정도 물기를 제거하였다. 물 기가 제거된 멥쌀에 미리 준비한 R. oryzae CCS01 현탁액 $(100 \mathrm{~mL})$ 과 멸균증류수 $(200 \mathrm{~mL})$ 를 차례로 가한 후 반죽하 였으며 누룩틀에 반죽을 채우고 다져 누룩을 성형하였다. 이후에는 각 성형된 누룩을 네모난 쟁반에 담고 한지로 덮은 후 균사 성장을 위해 $20^{\circ} \mathrm{C}$ 에서 5 일간 발효를 시켰다. 발효가 끝난 누룩은 자연건조 후 분쇄하여 분말 형태로 제조하였으며, 이 누룩은 냉장 $\left(4^{\circ} \mathrm{C}\right)$ 보관하면서 필요에 따 라 꺼내어 본 실험에 사용하였다.

\section{막걸리 담금 및 알코올 발효}

한국 고유 품종의 밀은 $1 \mathrm{~kg}$ 을 칭량하여 세척 후 충분한 물을 가수한 뒤 상온 $\left(15-25^{\circ} \mathrm{C}\right)$ 에서 4시간 침지 후 물기를 제거하고 $100^{\circ} \mathrm{C}$ 에서 1 시간 증자처리를 실시하였다.

막걸리 제조는 R. oryzae $\mathrm{CCS} 01$ 곰팡이 균주로 제조한 쌀 누룩과 시판 누룩(산성, 송학, 진주) $400 \mathrm{~g}$ 과 용수를 각각 $600 \mathrm{~mL}$ 를 발효조에 첨가하여 $25^{\circ} \mathrm{C}$ 에서 하룻동안 발 효시켜 밑술(1단 담금)을 제조하였다. 밑술 제조 후 미리 제조해 두었던 우리밀(증자) $400 \mathrm{~g}$ 을 추가로 투입시키고, 생균제제 효모 배양액 $50 \mathrm{~mL}(5 \%)$ 를 접종하여 $25^{\circ} \mathrm{C}$ 에서 7 일간 발효시켜 2 단 담금을 실시하였다. 7 일간 발효된 각 각의 막걸리는 4 겹의 여과천으로 여과한 것을 본 실험에 사용하였다.

\section{$\mathrm{pH}$ 및 산도}

$\mathrm{pH}$ 는 각각의 막걸리 $50 \mathrm{~mL}$ 를 비이커에 옮겨 담고 $\mathrm{pH}$ meter(MP 200, JenWay, London, UK)를 사용하여 측정하였 다. 산도는 $\mathrm{pH}$ 측정 후 $0.1 \mathrm{~N}-\mathrm{NaOH}$ 용액으로 중화적정 하여 $\mathrm{pH} 8.4 \pm 0.1$ 까지 중화하는데 소비된 $\mathrm{mL}$ 수를 구하고 acetic acid 양으로 환산하였다.

가용성 고형물 $\left({ }^{\circ} \mathrm{Brix}\right)$, 알코올 함량 및 갈변도 측정

가용성 고형물 함량은 각각의 막걸리들을 $16,500 \mathrm{rpm}$ 의 속도로 3분간 원심분리기(MF-530, Hannil, Seoul, Korea)로 상등액을 분리하고, 따로 취한 뒤 굴절당도계(Sccharometer, W.S.R.O-90, Atago Co., Tokyo, Japan)로 당도를 측정 하였다.

알코올 함량은 삼각플라스크에 각각의 막걸리 $(10 \mathrm{~mL})$ 와 물 $90 \mathrm{~mL}$ 를 첨가하고 소포제 일정량 $(0.3 \mathrm{~mL})$ 을 떨어뜨 린 후 증류과정을 거쳐 $20 \mathrm{~mL}$ 의 순수 알코올을 회수하였 다. 이후 $20 \mathrm{~mL}$ 의 알코올에 동량의 증류수를 가한 후 주정 계(MT-830, Atago Co., Tokyo, Japan)로 측정하여 \%로 나타 내었다.

갈변도는 막걸리 상등액을 일정량 취하여 분광광도계 (Spectonic 2D, Thermo, Electron Co., Marietta, OH, USA)를 사용하여 $420 \mathrm{~nm}$ 에서 측정하였으며 각 실험은 3회 반복수 행하여 평균값으로 나타내었다.

\section{유산균 및 효모 생균수 측정}

유산균수는 여과한 각각의 막걸리를 멸균생리식염수로 단계별 희석법을 통해 bromocresol purple(BCP) $0.02 \%$ 함 유 $\mathrm{MRS}$ 평판배지에 도말하고, $37^{\circ} \mathrm{C}$ 에서 2 일간 배양 후 황색 colony를 계수하였으며 효모는 chloramphenicol(1.5 $\mathrm{mg} / \mathrm{mL}$ ) 함유 PDA 배지에 도말하여 흰색의 탁한 전형적인 효모 colony를 계수하였으며, 각 실험은 3회 반복 수행 후 colony forming unit $(\log \mathrm{CFU} / \mathrm{mL})$ 으로 표시하였다. 


\section{통계분석}

각 실험 결과는 SPSS 12.0 package(IBM)를 사용하여 분산분석을 수행하였으며 평균표준편차로 나타내었다.

\section{결과 및 고찰}

생균제제(내산성, 펩신 저항성, 담즙산 내성) 효모 균주 선발 및 동정

본 연구에서 잠정적으로 선발된 효모 균주들의 산, 펩신, 담즙산에 대한 저항성 측정결과, 내산성의 경우 산 $(\mathrm{pH} 3.0)$ 조건에서 3 시간 이후 $50 \%$ 이상의 생존율을 보인 것은 $\mathrm{CCSY} 13$ 번 균주를 제외하고는 모두 식초에서 분리된 균주 (CCSY01, CCSY02, CCSY16, CCSY18 및 CCSY27)였고, 이들 중 $\mathrm{CCSY} 16$ 번 균주를 제외하고 모두 $\mathrm{pH} 3.0$ 조건에서 배양 3 시간 이후 $60 \%$ 이상의 생존율을 보였다(data not shown). 펩신 저항성 측정 결과로는 22종류의 효모 균주들 중 $\mathrm{CCSY} 01, \mathrm{CCSY} 02, \mathrm{CCSY} 13, \mathrm{CCSY} 18$ 번 균주가 3시간 후에도 $50 \%$ 이상의 생존율을 보였으며 특히 $\mathrm{CCSY} 27$ 번 균주는 $60.8 \%$ 로 가장 우수한 생존율을 나타내었다(data not shown). 담즙산 내성에서는 CCSY02 균주의 경우 담즙 산(1-4\%) 환경에서 생육속도가 가장 저조하였고, 이외 나머지 분리균주들은 생육속도가 활발한 것으로 조사되 었다(data not shown).

한편, 이 외에도 당과 알코올 내성 측정결과 대부분의 효모 균주들은 우수하였고 특히 CCSY27번 균주가 각종
내성과 알코올 생성력 및 발효특성이 가장 우수하여 막걸 리 제조를 위한 최적 균주로 선정하고 분자유전학적 동정 을 실시하였다. 생균제제 효모 CCSY27번 균주의 $26 \mathrm{~S}$ $\mathrm{rDNA}$ 염기서열을 NCBI data-base와 비교분석한 결과는 Fig. 1,2와 같았다. 그 결과, 기존에 알려진 Kazachstania exigua $\mathrm{CBS} 379$ 균주와 $99 \%$ 의 상동성을 나타내어 최종적 으로 본 연구에서 분리한 효모를 Kazachstania exigua CCSY27로 명명하였다.

\section{쌀-밀 막걸리 발효 중 $\mathrm{pH}$ 및 산도 변화}

생균제제 K. exigua CCSY27 효모를 이용하여 제조한 쌀-밀 막걸리와 시중에 판매 중인 산성, 송학, 진주 누룩으 로 제조한 쌀-밀 막걸리 및 R. oryzae 곰팡이를 이용하여 제조한 쌀-밀 막걸리의 발효 과정 중 $\mathrm{pH}$ 변화를 측정한 결과는 Fig. 3 과 같다. 시판 누룩(산성, 송학, 진주)은 발효 초기 $\mathrm{pH}$ 가 4.45(산성), 4.67(송학), 4.93(진주)에서 발효가 진행됨에 따라 조금씩 감소하여 발효 7일차에는 3.73(산 성), 3.78(송학) 및 3.74(진주) 수준이었고, R. oryzae 이용 쌀누룩은 발효초기 4.14에서 발효 7일차에 4.05로 약간 감소하였다. 한편, 산도는 발효초기 진주누룩이 $0.44 \mathrm{~mL}$ 로 가장 낮았으며, 산성누룩이 $0.86 \mathrm{~mL}$ 로 가장 높았으나 발효 1 일째 모든 누룩에서 산도가 급격히 증가하였고, 이후에는 서서히 증가하는 추세를 나타내었다. 쌀누룩의 경우 발효 초기 $0.68 \mathrm{~mL}$ 에서 발효 7일차에는 $1.12 \mathrm{~mL}$ 로 증가하였으 나 시판누룩은 쌀누룩보다 약 0.5-2.0배 정도 많은 양의

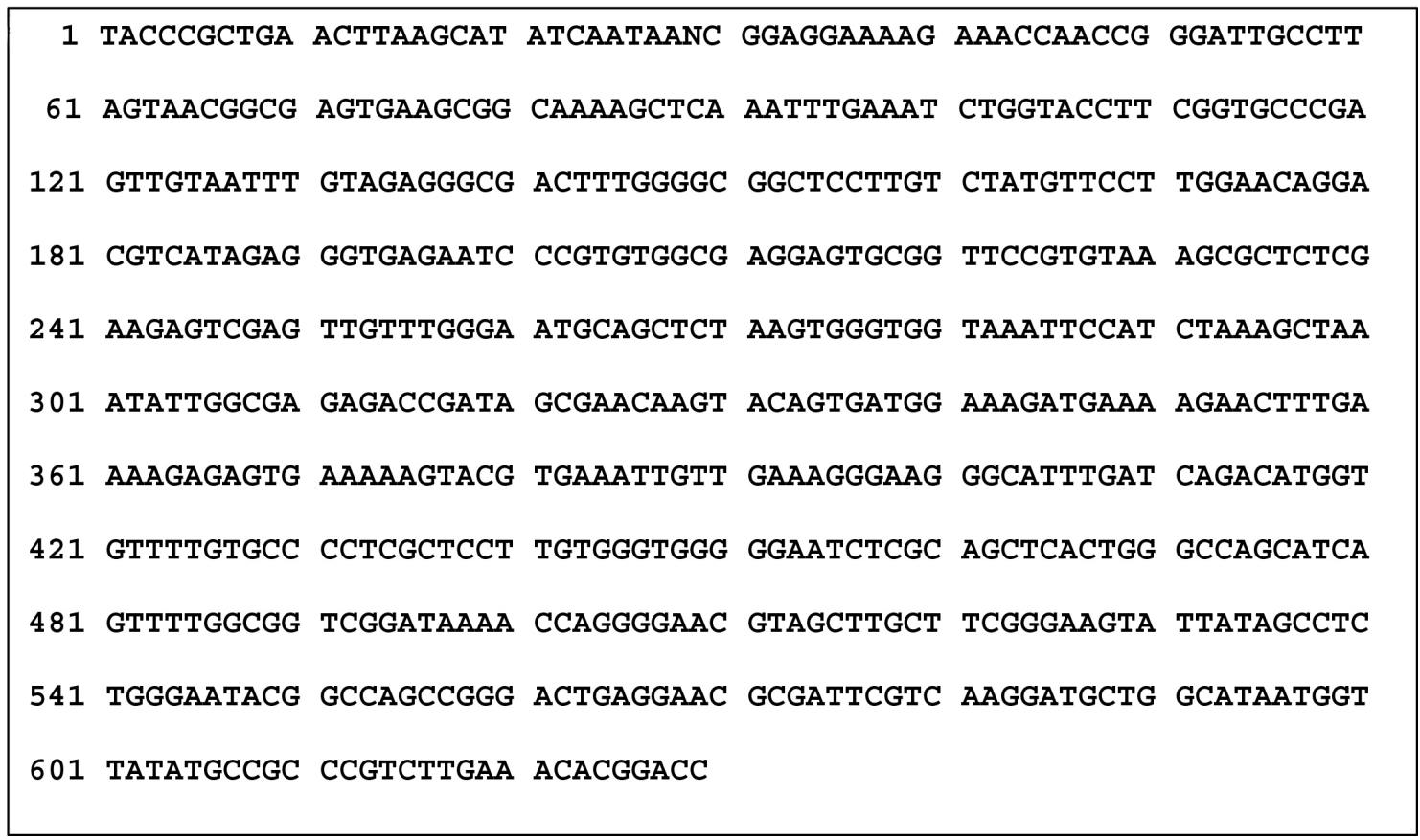

Fig. 1. 26S rDNA sequencing listing of CCSY27 strain. 


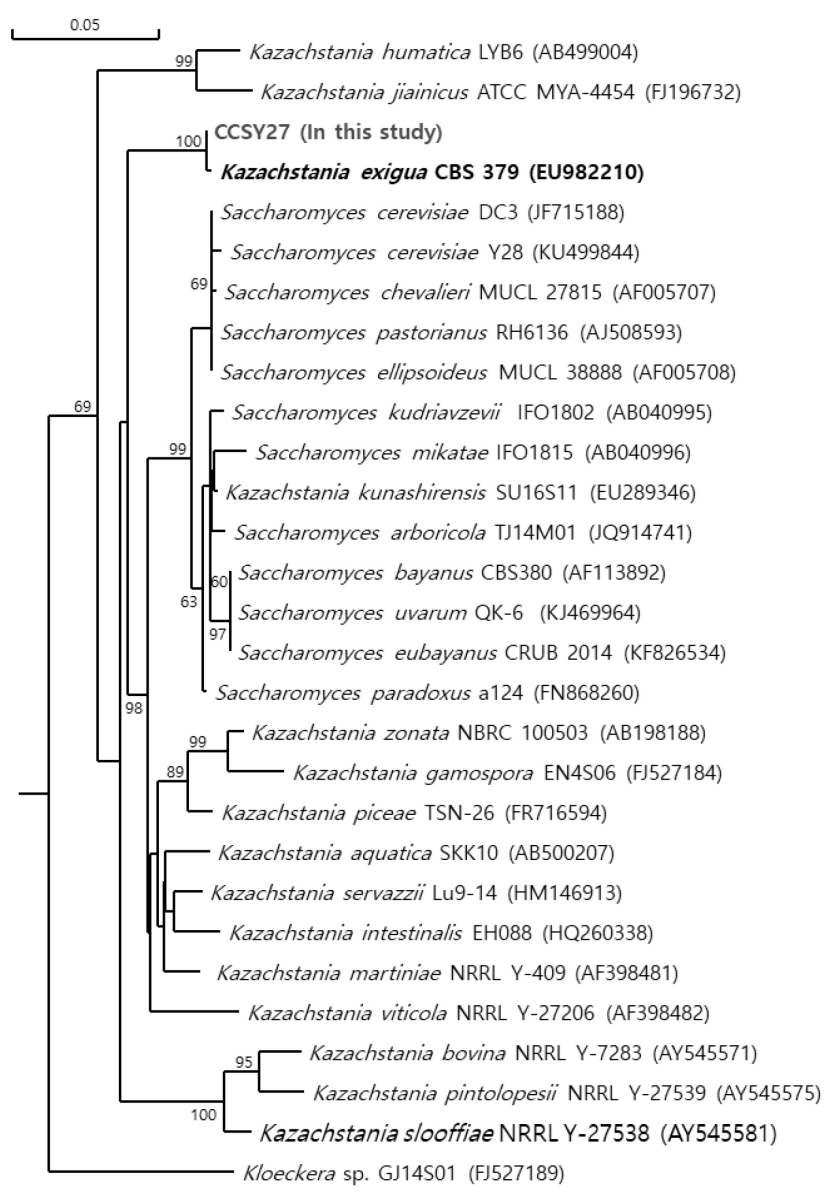

Fig. 2. Phylogenetic relationships of the strain CCSY27 and other closely related Kazachstania and Saccharomyces species based on 26S rDNA gene sequences.

Numbers above each node are confidence levels (\%) generated from 1,000 bootstrap trees. The scale bar is in fixed nucleotide substitutions per sequence position. Only values of $60 \%$ or above are shown.

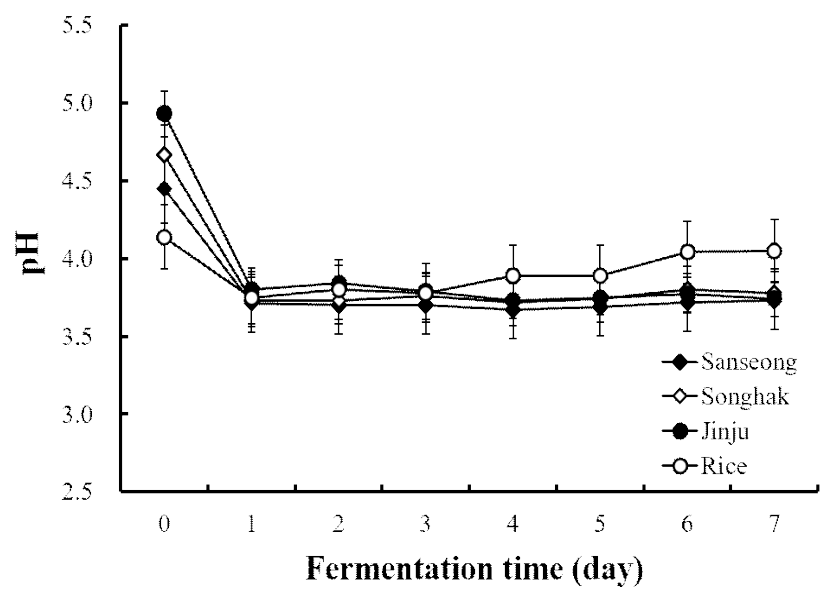

Fig. 3. Comparisons of $\mathrm{pH}$ value of the commercial 'Nuruk' and wheat-rice 'Makgeolli' by $K$. exigua CCSY27.
산이 생성되었다(Fig. 4). 막걸리의 품질은 알코올과 여러 영양성분에 의해서도 결정되지만 $\mathrm{pH}$ 역시 발효진행 상황 과 알코올 생성 정도를 대략 짐작할 수 있는 중요한 인자 중 하나이다(Kim과 $\mathrm{Yi}, 2010)$. Seo 등(2012)의 R. oryzae $\mathrm{CCS} 01$ 곰팡이로 제조한 쌀-밀 막걸리 연구에서는 발효초 기 $\mathrm{pH}$ 는 급격히 감소하였으나 발효가 진행될수록 점차적 으로 증가하였고, 이는 본 연구에서의 $\mathrm{pH}$ 변화와도 유사한 패턴을 보였다. Choi 등(2011)의 보고 역시 시판누룩으로 석탄주를 제조하고 발효하였을 시 발효 초기 $\mathrm{pH}$ 는 급격히 감소한 반면, 발효 중기부터 완만히 증가한다고 하여 이 또한 본 연구 결과와도 일치하였다. 일반적으로 $\mathrm{pH}$ 가 감소 하면 이에 비례적으로 총산은 증가하며 $\mathrm{pH}$ 가 증가하게 되면 총산 역시 비례적으로 감소해야 하나, 본 연구뿐만 아니라 여러 막걸리 관련 연구에서는 총산이 증가하는 것으로 보고되었다. 이와 관련해서 여러 연구에서는 보통 발효 중기부터 발효산물인 아미노산과 펩타이드 완충작 용에 의해 $\mathrm{pH}$ 와 총산 모두 증가하는 것이라 보고되었다 (Kim 등, 2011b; Seo 등, 2012).

\section{쌀-밀 막걸리 발효 중 가용성 고형물, 알코올 함량 및 갈변도 변화}

K. exigua CCSY27 효모를 이용하여 제조한 쌀-밀 막걸 리와 시판누룩으로 제조한 쌀-밀 막걸리의 가용성 고형물 함량을 측정한 결과는 Fig. 5 에 나타낸 바와 같다. ${ }^{\circ} \mathrm{Brix}$ 는 발효초기 $2.6{ }^{\circ} \mathrm{Brix}\left(\right.$ 쌀누룩), $2.4{ }^{\circ} \mathrm{Brix}\left(\right.$ 송학), $3.2{ }^{\circ} \mathrm{Brix}($ 산성 $)$ 및 $2.6^{\circ} \mathrm{Brix}$ (진주)에서 발효 2 일째 급격히 증가하여 7.2 ${ }^{\circ} \mathrm{Brix}\left(\right.$ 쌀누룩 및 송학), $7.4{ }^{\circ} \mathrm{Brix}\left(\right.$ 진주)와 $8.0{ }^{\circ} \mathrm{Brix}$ (산성) 수준이었고, 이후 발효가 진행됨에 따라 서서히 증가하여 발효 7 일차에는 $8.8{ }^{\circ} \mathrm{Brix}$ (송학), $8.6{ }^{\circ} \mathrm{Brix}$ (진주), 및 9.2

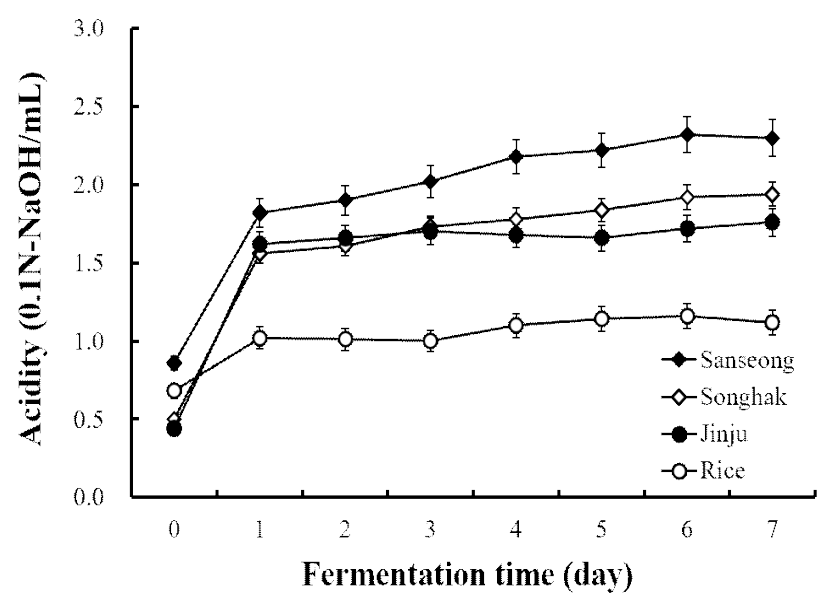

Fig. 4. Comparisons of acidity value of the commercial 'Nuruk' and wheat-rice 'Makgeolli' by $K$. exigua CCSY27.

Sanseong, songhak, and jinju: commercial 'Nuruk'. Rice: Using Rhizopus oryzae CCS01. 


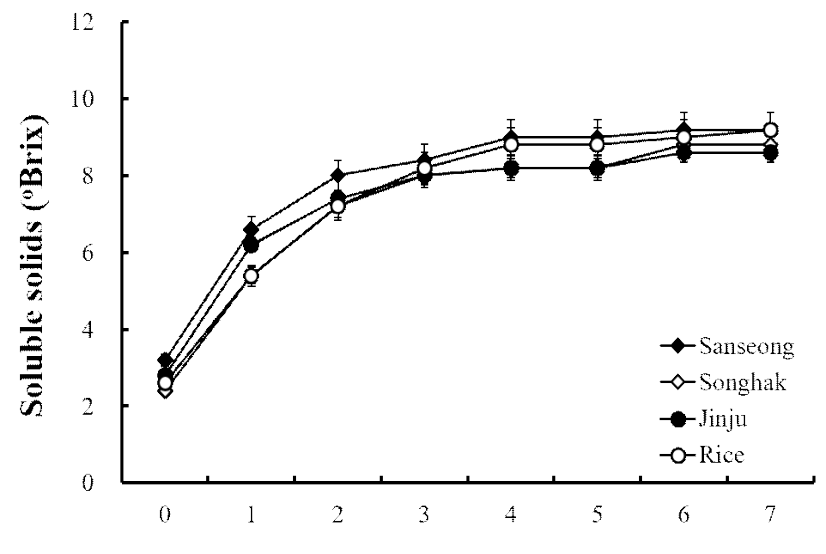

Fermentation time (day)

Fig. 5. Comparisons of soluble solid content of the commercial 'Nuruk' and wheat-rice 'Makgeolli' by $K$. exigua CCSY27.

Sanseong, songhak, and jinju: commercial 'Nnuruk'

Rice: Using Rhizopus oryzae CCS01.

${ }^{\circ} \operatorname{Brix}($ 쌀누룩 및 산성) 수준을 나타내었다(Fig. 4). 한편, 알코올 함량은 발효 1 일차에 $6 \%$ (산성), $4 \%$ (송학 및 진주) 를 나타내었고 쌀누룩의 경우 $7 \%$ 로 알코올 함량이 가장 높았다(Fig. 6). 이후 발효 기간이 경과함에 따라 알코올은 꾸준히 증가하는 경향을 나타내었고 발효 7일차에 각각 $9 \%$ (산성), $8.8 \%$ (송학), $8.6 \%$ (진주), 쌀누룩은 $13.6 \%$ 로 알 코올 함량이 가장 많이 생성되었다. 막걸리 발효 중 갈변도 변화는 발효가 진행됨에 따라 서서히 증가하였고 발효 7일차에 각각 1.008 (산성), 0.623(송학), 0.877(진주), 0.428 (쌀누룩)의 흡광도 수치를 나타내었으며 시판누룩으로 제 조한 막걸리는 쌀누룩으로 제조한 막걸리보다 약 0.5-2.0 배 정도 갈변도가 높은 것으로 나타났다(Fig. 7). 부가적으

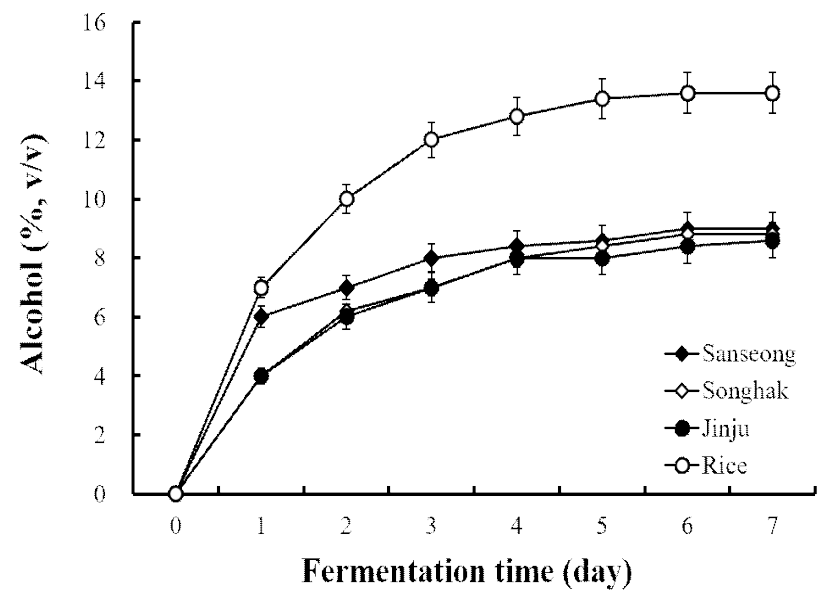

Fig. 6. Comparisons of alcohol content of the commercial 'Nuruk' and wheat-rice 'Makgeolli' by $K$. exigua CCSY27.

Sanseong, songhak, and jinju: commercial 'Nnuruk'. Rice: Using Rhizopus oryzae CCS01.

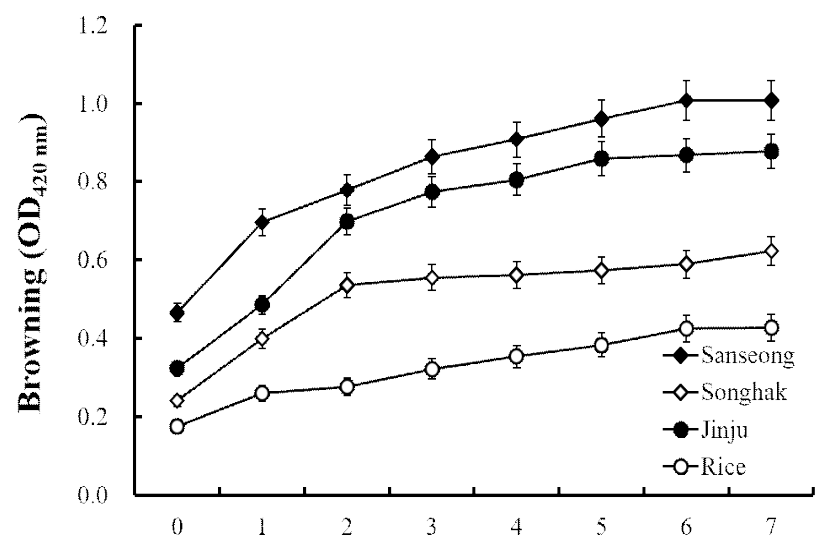

Fermentation time (day)

Fig. 7. Comparisons of browning value of the commercial 'Nuruk' and wheat-rice 'Makgeolli' by $K$. exigua CCSY27.

Sanseong, songhak, and jinju: commercial 'Nnuruk'. Rice: Using Rhizopus oryzae CCS01.

로, 유산균과 효모의 생균수는 발효초기 $10^{4}$ (효모) $-10^{5}$ (유 산균) 수준이었고, 발효 7일차에는 유산균과 효모 모두 $10^{7}$ 의 세포수를 나타내었으며 시판누룩에서는 특유의 누 룩치가 잔존하여 관능적으로 음용하기에는 조금 부담스 러운 것으로 조사되었다(data not shown).

당의 존재는 발효 과정 중에 효모의 알코올 생성기작에 직접적으로 관여하며 특히, 가용성 고형물 증가 현상은 누룩 발효 과정 중 곰팡이 유래 전분 분해효소에 의해 $\alpha$-amylase와 glucoamylase 활성 증가와 직접적인 요인이 있는 것으로 보고되었다(Park 등, 2013). Seo 등(2012)의 연구 역시 막걸리 발효 중 당도는 꾸준히 증가하였고 Kim 등(2012)의 설기떡과 마늘을 첨가한 막걸리 발효 연구 결 과 역시 발효 진행에 따라 순차적으로 증가한다고 보고하 였고 이는 본 연구 결과와도 일치하였다. 한편, 알코올은 주류의 보존성에도 영향을 미치지만, 향미에 영향을 주는 중요한 성분으로 술덧의 알코올 함량은 높아야 한다고 보고되었으며(Seo 등, 2012), $\alpha$-amylase 효소활성도에 따라 알코올 생성량이 결정된다(Seo 등, 2012). 특히 Seo 등 (2012)의 쌀-밀 막걸리 연구에서는 실제로 각 누룩들의 $\alpha$-amylase 활성을 측정한 결과, 시판누룩(산성, 송학, 진주) 보다는 쌀누룩에서 $\alpha$-amylase 활성이 가장 높았고 이에 따라 알코올 함량 역시 가장 높았으며, 이 결과는 본 연구 에서도 마찬가지로 쌀누룩의 알코올 함량이 $7 \%$ 로 가장 높았으며 $\alpha$-amylase 활성도와 알코올 생성력은 비례하는 것으로 나타났다.

이로써 한국 고유의 품종인 우리밀(금강)과 한국의 전통 누룩에서 분리한 R. oryzae CCS01 균주와 생균제제능이 우수한 $K$. exigua CCSY27 효모 균주 사용 막걸리 연구는 수입 품목에 의존하지 않고 한국 고유의 미생물과 누룩을 
이용한 점에 대해 학술적인 의미가 우수할 것으로 사료된 다. 특히, 우리술의 새로운 전성기가 도래하고 있는 현 시점에서 본 연구 결과는 앞으로 다양한 형태의 막걸리 제조에 관한 기초자료로써 활용 가능할 것으로 판단된다.

\section{요 약}

본 연구에서는 발효 동안 Kazachstania exigua CCSY27 균주와 시판누룩(산성, 송학, 진주)으로 제조된 막걸리(쌀 누룩)의 품질 특성을 비교 평가하였다. 발효 중 시판누룩 (산성, 송학, 진주) 및 막걸리의 $\mathrm{pH}$ 는 감소한 반면 산도는 약간 증가하였다. 특히, 시판누룩은 막걸리보다 약 0.5 2.0 배 높은 산도를 나타내었다. 발효 2일 후에는 가용성 고형물 함량이 급격히 증가하였고, 발효 7일 후에는 쌀누 룩과 산성 누룩은 $9.2{ }^{\circ} \mathrm{Brix}$ 로 가용성 고형물 함량이 가장 많이 증가하였다. 쌀누룩의 알코올 함량은 $7 \%$ 로 시판누룩 (산성, 송학, 진주)보다 높았으며 전체적인 기호도 측면에 서도 가장 우수하였다. 발효 과정에서 쌀누룩과 시판누룩 의 갈변도는 서서히 증가하였고 발효 7일째에 산성 누룩이 가장 높았다. 한편, 각각의 누룩에서, 발효 기간 동안 유산 균 및 효모의 생균의 세포 수는 $10^{4}-10^{7}(\log \mathrm{CFU} / \mathrm{mL})$ 수준 을 나타내었다.

\section{감사의 글}

이 논문은 2018년 국립경남과학기술대학교의 연구비 지원에 의하여 연구되었습니다.

\section{Conflict of interests}

The authors declare no potential conflict of interest.

\section{ORCID}

Chung Eun Hwang https://orcid.org/0000-0002-7130-1818 OK Soo Joo https://orcid.org/0000-0002-8905-9820

\section{References}

Cho HK, Seo WT, Lee JY, Cho KM. Quality characteristics of cereal makgeolli rice nuruk prepared Rhizopus oryzae CCS01. Korean Soc Food Sci Nutr, 41, 1002-1008 (2012)

Choi JH, Jeon JA, Jung ST, Park JH, Park SY, Lee CH, Kim TJ, Choi HS, Yeo SH. Quality characteristics of Seoktanju fermented by using different Nuruks. Korean J Microbiol Biotechnol, 39, 56-62 (2011)
Han EH, Lee TS, Noh BS, Lee DS. Volatile flavor components in mash of Takju prepared by suing different Nuruks. Korean J Food Sci Technol, 29, 563-570 (1997)

Ha CG, Cho JK, Chai YG, Heo KC. Isolation and identification of lactic acid bacteria containing superior activity of the bile slats deconjugation. Food Sci Anim Resour, 24, 164-170 (2004)

Jeong JW, Park KJ, Kim MH, Kim DS. Quality characteristics of Takju fermentation by addition of chestnut peel powder. Korean J Food Preserv, 13, 329-336 (2006)

Jung SE, Kim SH. Probiotic properties of lactic acid bacteria isolated from commercial raw makgeolli. Korean J Food Sci Technol, 47, 44-50 (2015)

Joo OS, Kang ST, Jeong CH, Lim JW, Park YG, Cho KM. Manufacturing of the enhances antioxidative wine using a ripe Daebong persimmon (Dispyros kaki L). J Appl Biol Chem, 54, 126-134 (2011)

Kim GM, Jung WJ, Shin JH, Kang MJ, Sung NJ. Preparation and quality characteristics of makgeolli made with black garlic extract and sulgidduk. J Korean Soc Food Sci Nutr, 40, 759-766 (2011a)

Kwak HJ, Kim JY, Lee HS, Kim SM. Formation of biogenic amines by Lactobacillus plantarum isolated from makgeolli. Korean J Food Sci Technol, 46, 438-445 (2014)

Kang KM, Lee SH. Physiological characteristics of starter isolated from Kimchi and fermentation of tofu with isolated starter. Korean J Soc Food Sci Nutr, 41, 1626-1631 (2012)

Kim YJ, Ju JC, Kim RY, Kim WT, Park JH, Chun SS. Cooking properties of fresh pasta using Korean wheat and Durum rimachinata. J Korean Soc Food Sci Nutr, 40, 1474-1481 (2011b)

Kim JY, Sung KW, Bae HW, Yi YH. pH, acidity, color, reducing sugar, total sugar, alcohol and organoleptic characteristics of puffed rice powder added takju during fermentation. Korean J Food Sci Technol, 39, 266-271 (2007)

Kim YH, Min JH, Kang MG, Kim JH, Ahn BH, Kim HK, Lee JS. Physicochemical properties, lactic acid bacteria content and physiological functionalities of Korean commercial Makgeolli. Korean J Microbiol Biotechnol, 40, 325-332 (2012)

Kim JY, Yi YH. pH, acidity, color, amino acids, reducing sugars, total sugars, and alcohol in puffed millet powder containing millet Takju during fermentation. Korean J Food Soi technology, 42, 727-732 (2010) 
Kim SY, Kim EK, Yoon SJ, Jo NJ, Jung SK, Kwon SH, Chang YH, Jeong YH. Physicochemical and microbial properties of Korean traditional rice wine, Makgeolli supplemented with cucumber during fermentation. J Korean Soc Food Sci Nutr, 40, 223-228 (2011c)

Kim JW, Kang JE, Choi HS, Kim CW. Analysis of the physicochemical characteristics and sensory properties in makgeolli. J East Asian Diet Life, 27, 491-499 (2017)

Lee HS, Park YS, Bai DH. Quality characteristics of makgeolli (rice wine) fermented with koji by starch types. Food Eng Prog, 18, 215-221 (2014)

Park JH, Choi JH, Yeo SH, Jeong ST, Choi HS, Kang JE, Kim SR. A study on the quality charactsristics of makgeolli using heat treatment of traditional Korean nuruk extract. J East Asian Soc Dietary Life, 23, 620-628 (2013)

Park HY, Choi ID, Oh SK, Woo KS, Yoon SD, Kim HJ, Sim EY, Jeong ST. Effects of different cultivars and milling degrees on quality characteristics of barley makgeolli. J Korean Soc Food Sci Nutr, 44, 1839-1846 (2015)

Rhee YK, Nam SH, Kim HR, Cho CW, Lee YC, Kim YC, Hong HD. Effect of crude polysaccharide isolated from makgeolli mash under different fermentation conditions on immunestimulating activity. J Korean Soc Food Sci Nutr, 43, 1835-1842 (2014)

Seo WT, Cho HK, Lee JY, Kim B, Cho KM. Quality characteristics of wheat-rice makgeolli by making of rice nuruk prepared by Rhizopus oryzae CCS01. Korean J Microbiol, 48, 147-155 (2012)
Song JC, Park HJ. Takju brewing using the uncooked germed brown rice at second stage mash. J Koran Soc Food Sci Nutr, 32, 847-854 (2003)

Song JH, Lee JS, Lee EN, Lee SW, Kim JH, Lee JS. Manufacture and quality characteristics of Korean traditional gugija (Lycii fructus) Takju. Korean J Food Nutr, 22, 86-91 (2009)

Shin DS, Jeong ST, Sim EY, Lee SK, Kim HJ, Woo KS, Oh SK, Kim SJ, Park HY. Quality characteristics of mixed makgeolli with barley and wheat by fermentation temperature. Korean J Food Nutr, 30, 305-311 (2017)

Sim HS, Kim MD. Antipathogenic activity of Bacillus amyloliquefaciens isolated from Korean traditional rice wine. Korean J Microbiol Biotechnol, 44, 98-105 (2016)

So MH, Lee YS. Effects of culture conditions of Rhizopus sp. ZB9 on the production of saccharifying amylase during the preparation of rice koji. Korean J Food Nutr, 22, 644-649 (2009)

Woo SM, Shin JS, Seong JH, Yeo SH, Choi JH, Kim TY, Jeong YJ. Quality characteristics of brown rice takju by different Nuruks. J Korean Soc Food Sci Nutr, 39, 301-307 (2010a)

Woo KS, Ko JY, Song SB, Lee JS, Oh BG, Kang JR, Nam MH, Ryu IS, Jeong HS, Seo MC. Physicochemical characteristics of Korean traditional wine prepared by addition of sorghum (Sorghum bicolor L. Moench) using different nuruks. J Korean Soc Food Sci Nutr, 39, 548-553 (2010b) 